\title{
Study of aerobic granulocyte functional activity in the presence of a radiosensitizer (metronidazole)
}

E.A.A. Al-Krawi and A.H.M. Al-Hashimi²

$$
\begin{aligned}
& \text { در اسة النشاط الوظيفي للمحبـبات الحيو ائية في وجود محفِّز للحساسية للأشعة (المتـرونيدازول) } \\
& \text { ابتهال علي عباس الكروي، علئي حسين محمد الهاشمي }
\end{aligned}
$$

الخلاصـة: تمت دراسة تأثيرات المتـرونيدازول في المختبر على إنتاج الأنواع المتفاعلة مع الأكسجين بفعل الخلايا

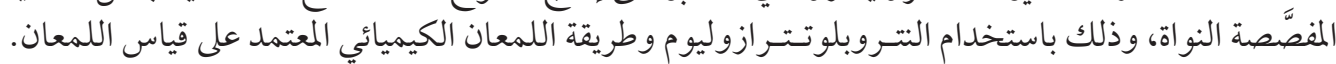

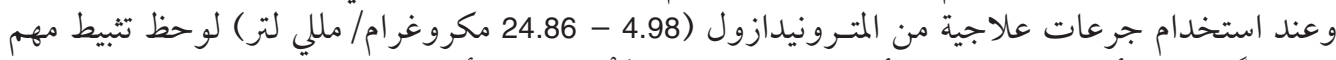

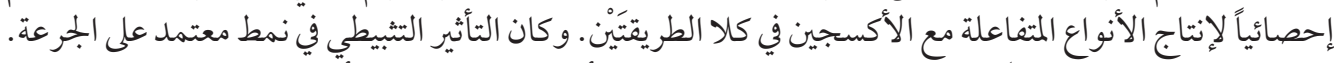

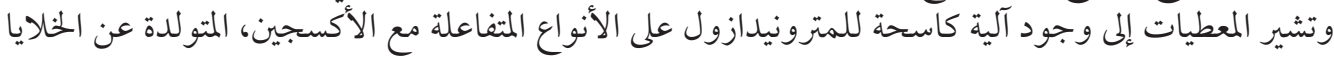
المفصصة النواة.

ABSTRACT The in vitro effects of metronidazole on the production of reactive oxygen species by polymorphonuclear (PMN) cells were studied by means of nitroblue tetrazolium and luminol-dependent chemiluminescence. At therapeutic doses of metronidazole $(4.98-24.86 \mu \mathrm{g} / \mathrm{mL})$ significant inhibition of the production of reactive oxygen species was noted in both methods. The inhibitory effect was in a dose-dependent pattern. The data suggest a scavenging mechanism of metronidazole on reactive oxygen species generated by PMN.

Étude de l'activité fonctionnelle aérobie des granulocytes en présence d'un radiosensibilisant (métronidazole)

RÉSUMÉ Les effets in vitro du métronidazole sur la production d'espèces réactives de l'oxygène par les cellules polymorphonucléaires (PMN) ont été étudiés grâce au test au nitrobleu de tétrazolium et au test de chimioluminescence au luminol. À des doses thérapeutiques de métronidazole $(4,98-24,86 \mu \mathrm{g} / \mathrm{mL})$, on a observé une inhibition significative de la production d'espèces réactives de l'oxygène avec les deux méthodes. L'effet inhibiteur dépendait de la dose utilisée. Les données obtenues semblent indiquer que le métronidazole agit en tant que piégeur des espèces réactives de l'oxygène générées par les PMN.

\footnotetext{
${ }^{1}$ Department of Pharmacology; ${ }^{2}$ Department of Physiology, Basra College of Medicine, University of Basra, Basra, Iraq (Correspondence to A.H.M.Al-Hashimi: ahalh_alhshimi@yahoo.com).

Received: 12/09/04; accepted: 27/03/06
} 


\section{Introduction}

Radiosensitizers are chemical agents that have the potential to increase the lethal effect of radicals induced during irradiation [1-6]. The extent of radiation damage to cells is dependent on the amount of oxygen available to the cell $[1,2,7,8]$. Hypoxic cancer cells are known to be relatively resistant to radiation killing compared with well oxygenated healthy cells $[2,3,7-9]$.

Metronidazole (Flagyl) is a drug used to treat infections and has been studied in the treatment of cancer $[10,11]$ as a radiosensitizer drug, especially for hypoxic cells [9]. Metronidazole selectively radiosensitizes hypoxic cells without influencing the radiation response of normal well-oxygenated cells [5,7-9].

The radiosensitizing property of metronidazole may be related to its electron affinity or oxidizing power $[2,5,9,12,13]$. It is worth mentioning that many of the electronaffinic radiosensitizers of hypoxic cells also have the property of preferential or selective toxicity directed against hypoxic cells even in the absence of radiation $[1,2]$.

Metronidazole, being electron-affinic, can accept an electron from neutral free radical centres to generate a reactive cation that binds to an anion such as hydroxyl $\left(\mathrm{OH}^{-}\right)$, causing a permanent lesion. Under aerobic conditions, there is enough oxygen to react with all the free radicals and addition of metronidazole, or any other sensitizers, yields no further benefit. Thus metronidazole does not show any radiosensitizing ability when tested under aerobic conditions $[5,9,12,13]$.

Metronidazole is heterocyclic nitro derivative in which the nitro group of metronidazole is reduced by an electron transport protein such as NADPH in an anaerobic micro-organism $[6,7,12,13]$.

While the antimicrobial effect of metronidazole is is well known, [14-16], there have been few studies on the influence of metronidazole on the phagocytosis functional activity of polymorphonuclear cells $(\mathrm{PMN})$ in whole blood, in which the function of the granulocytes often seems to be altered. In the presence of $\mathrm{O}_{2}$ the generation of free radicals from the stimulation of PMN results in the production of superoxide radicals $[7,8]$. With intact cells, the formation of oxygen reactive intermediates leads to the production of $\mathrm{H}_{2} \mathrm{O}_{2}$ which can be measured in the presence of NBT (optical density changes due to NBT reduction) [17] or by luminol induced CL [18].

We aimed therefore to study the effect of metronidazole (in a range of therapeutic concentrations) on PMN-generated free radicals during phagocytosis activity in whole blood under normal aerobic conditions in vitro (in the absence of ionizing radiation). Whole blood was used to mirror the in vivo situation where blood cells are suspended in their original medium.

\section{Methods}

All chemical reagents were obtained from Sigma Chemical Company, Germany, unless otherwise mentioned.

\section{Blood samples}

Venous blood samples were obtained from apparently healthy volunteers aged 30-55 years using vials with heparin as the anticoagulant. The samples were kept at $4{ }^{\circ} \mathrm{C}$ until the start of the assay.

Ethical consent was obtained from the local ethical committee for all parts of the study.

\section{Chemicals and reagents}

Tris- $\mathrm{HCl}$ stock solution was prepared using the following procedure: $24.2 \mathrm{~g}$ of Tris (Fluka-Garantte, Germany) was dissolved 
in $1000 \mathrm{~mL}$ distilled water, then $50 \mathrm{~mL}$ of the Tris solution was added to $41.4 \mathrm{~mL}$ of $0.2 \mathrm{M} \mathrm{HCl}$ (Fluka-Garantte) and diluted to $200 \mathrm{~mL}$ with distilled water. The final Tris- $\mathrm{HCl}$ solution molarity was $0.015 \mathrm{M}$ at $\mathrm{pH} 7.4$.

\section{Nitroblue tetrazolium}

Nitroblue tetrazolium (NBT) (Sigma) is an electron acceptor used to detect indirectly the production of the super oxide radical $\left(\mathrm{O}^{-}\right)$by stimulated PMNs, thus providing a quantitative means to identify cells producing $\mathrm{O}_{2}^{-}$. This can be quantitated spectrophotometrically. We used $0.2 \%$ NBT in Tris-HCl solution. Heparinized blood was used for the activated NBT test; heparin forms a complex with NBT that is then ingested by PMNs, thus reducing the NBT [17].

\section{Luminol solution}

This was made by dissolving $0.02 \mathrm{mg}$ luminol (Sigma) in $1 \mathrm{~mL}$ dimethylsulfoxide. This stock solution was further diluted with Tris- $\mathrm{HCl}$ solution to give about $10^{6} \mathrm{M}$ of luminol solution prior to use.

\section{Metronidazole solution}

Metronidazole, concentration $500 \mathrm{mg} / 100 \mathrm{~mL}$, was obtained (Factory for Medical Solutions, Jeddah, Saudi Arabia). The 100 $\mathrm{mL}$ contains, $500 \mathrm{mg}$ metronidazole BP, $740 \mathrm{mg}$ sodium chloride, $44 \mathrm{mg}$ citric acid monohydrate, $135 \mathrm{mmol} / \mathrm{L} \mathrm{Na}^{+}, 150 \mathrm{mg}$ sodium monohydrogen phosphate, $12 \mathrm{mmol}$ $\mathrm{H}_{2} \mathrm{O}_{2}, 126.6 \mathrm{mmol} / \mathrm{L} \mathrm{Cl}^{-}, 4.20 \mathrm{mmol} / \mathrm{L} \mathrm{PO}_{4}{ }^{-3}$. Osmolarity wa $297 \mathrm{mosm} / \mathrm{L}$. Different drug concentrations were obtained by dilution with normal Tris- $\mathrm{HCl}$ solution.

\section{Procedure}

The test samples were incubated for 60 minutes with different concentrations of metronidazole. Control samples were incu- bated under the same conditions as the test samples but without the drug. The test samples contained $0.5 \mathrm{~mL} \mathrm{NBT}$ solution +0.5 $\mathrm{mL}$ whole blood $+2 \mathrm{~mL}$ metronidazole in the following 5 concentrations: $4.98,6.64$, $11.62,16.60$ and $34.86 \mu \mathrm{g} / \mathrm{mL}$. The control samples contained $0.5 \mathrm{~mL}$ NBT solution $+0.5 \mathrm{~mL}$ whole blood $+2 \mathrm{~mL}$ Tris-HCL solution

All samples were incubated at $37{ }^{\circ} \mathrm{C}$ for $1 \mathrm{~h}$ and spun for 3 minutes at $3000 \mathrm{rpm}$. The supernatant was carefully removed and placed in the spectrophotometer cuvette. The optical density (\% absorption) was measured at $515 \mathrm{~nm}$ using Philips spectrophotometer (type PU8620).

\section{Chemiluminescence measurement}

Test and control samples were assayed for PMN functional activity (free radical concentration released) [18].

The reaction mixture consisted of $0.02 \mathrm{~mL}$ luminol in a $5 \mathrm{~mL}$ beaker and $0.01 \mathrm{~mL}$ whole blood, agitated to mix well, before placing it into the measuring cuvette of the photon counting system. Chemiluminescence (CL) was continuously recorded on a chart recorder until it peaked and demonstrated a definite decline. The peak height (in $\mathrm{mm}$ ) of CL kinetic curves represents the granulocyte functional activity. The data were estimated in relative arbitrary units for comparison of the results.

\section{Statistical analysis}

The results of both NBT reduction and CL measurement (the peak height in $\mathrm{mm}$ to be proportional to the area under the CL kinetic curve) were estimated relative to the control in each test. Data are expressed as mean and standard deviation of at least 2 observations. Results were analysed for significance using the $t$-test, with a P-value $<0.05$ indicating statistical significance. 


\section{Results}

Treatment of PMN cells in whole blood with metronidazole therapeutic doses resulted in a statistically significant inhibition of free radicals generated by the granulocytes which followed a dose-dependent pattern.

Table 1 shows the reduction of NBT and the inhibition of the luminol-dependent CL activity of PMN in whole blood as a function of drug concentration.

\section{Discussion}

Significant decreases in both the reduction of NBT and in CL were observed at different concentrations of the drug $(P<$ $0.01)$. These results indicate that metronidazole reacts directly with the reactive oxygen species generated by PMN due to its high electron affinity $[12,13,19]$. The drug therefore displays a scavenging mechanism which operates in a dose-dependent manner (Table 1).

The reducing effect of the high electron affinity of nitro group themselves is much less than that of oxygen $[7,8,19]$. Inhibition of CL by direct electron transfer from the cellular pool of reducing agents (such as $\mathrm{NADPH}$ ) to the high electron affinity nitro group may be the mechanism. Therefore, the extent of the stimulation of oxygen consumption that might occur during metabolism will be affected $[7,8,19]$. Alternatively, the nitro group may react directly with molecular oxygen and prevent the formation of $\mathrm{H}_{2} \mathrm{O}_{2}$. In our study the drug might mediate the cellular pools in cell respiration during metabolism $[7,8,12,19]$.

We found all concentrations of the drug were inhibitory and the inhibition was dose dependent. The degree of inhibition increased with the time of incubation with the drug (maximum inhibition was within about 30 minutes of incubation with the all drug concentrations; data not shown) suggesting depletion of reducing equivalents, i.e. intermediates (e.g. NADPH) which serve as electron sources in cell respiration [12]. Similar effects due to depletion of electron sources have been reported for 5-nitroindazole and derivatives [10,11], which are known to stimulate cellular oxygen utilization.

The NBT test provides an easy method to screen PMN cell activity for its capacity

\begin{tabular}{|c|c|c|c|c|}
\hline $\begin{array}{l}\text { Drug concentration } \\
(\mu \mathrm{g} / \mathrm{mL})\end{array}$ & $\begin{array}{l}\text { NBT reduction } \\
\text { (absorption) }\end{array}$ & $\begin{array}{l}\% \text { NBT } \\
\text { reduction }\end{array}$ & $\begin{array}{c}\text { Mean (SD) CL } \\
\text { peak height }(\mathrm{mm})\end{array}$ & $\%$ CL inhibition \\
\hline 0 (control) & 0.881 & 0 & $117(60)$ & 0 \\
\hline 4.98 & 0.760 & 13.7 & $102(5)$ & 12.8 \\
\hline 6.64 & 0.647 & 26.6 & $87(7)$ & 25.6 \\
\hline 11.62 & 0.566 & 35.7 & $74(6)$ & 36.8 \\
\hline 16.60 & 0.503 & 42.9 & $68(7)$ & 41.9 \\
\hline 34.86 & 0.121 & 86.2 & $17(3)$ & 85.5 \\
\hline$P$-value & \multicolumn{2}{|c|}{0.01} & \multicolumn{2}{|c|}{0.01} \\
\hline
\end{tabular}

a SD for NBT readings were too small to be considered.

Measurements were in duplicate.

$S D=$ standard deviation .

المجلة الصحية لشرق المتوسط، منظمة الصحة العالمية، المجلد الخامس عشر، العدد (، 9 +. 
to undergo oxidative metabolism. Failure by PMNs to reduce NBT may be due to the rapid depletion of NADPH reduction capacity in the cell, which leads to very little $\mathrm{O}_{2}$ production when stimulated.

It has been reported that metronidazole protects tissue from NSAID-induced enteropathy [20]. The possible mechanism is due to its reduction of the increase in mitochondrial oxygen consumption induced by NSAID (caused by coupling of mitochondrial oxidative phosphorylation) [20,21]. Our result conforms with this as metronidazole caused a significant reduction in the free radicals generated by PMN in the luminol-dependent chemiluminescence.

Metronidazole in the therapeutic range studied in this work does not alter the func- tional activity of PMN in whole blood. The inhibition of CL signal or the reduction in the absorbance by NBT is due to the scavenger effect of the drug at the extracellular level (phagocytosis of foreign particles did occur; image slides not shown).

In conclusion, the electron affinity properties of metronidazole allow it to react with metabolic reducing agents (such as NADPH) and oxygen radicals, which prevents the formation of $\mathrm{H}_{2} \mathrm{O}_{2}$, the oxidizing agent formed during metabolic activity. Our data conform with the idea of the scavenger effect of metronidazole on active oxygen radicals generated in the cell $[20,21]$.

\section{References}

1. Robert AF, ed. Free radicals and cancer. New York, Marcel Dakker, 1982:325.

2. Stratford IJ. Bioreductive drugs in cancer therapy. In: Denkamp J, Hirst DG, Eds. Radiation science: of molecules, mice and men. London, British Institute of Radiology, 1992:128-36 (British journal of radiology supplement 24$)$.

3. Zharkov VV et al. [The immediate results of the use of isometronidazole in the combination therapy of patients with lung cancer]. Meditsinskaia radiologiia, 1991, 36(7):18-20 [In Russian].

4. Wong $\mathrm{KH}$, Maezawa H, Urano M. Comparative study of thermoradiosensitization by misonidazole and metronidazole in vivo: antitumour effect and pharmacokinetics. International journal of hyperthermia, 1992, 8(5):645-58.

5. Acharya DK. Role of metronidazole in radiation therapy (a review of 717 cancer cases). Indian journal of medical sciences, 1994, 48(5):111-6.
6. Galecki J et al. [Comparison of the effectiveness of different methods of irradiation using metronidazole as a radiation-sensitizing agent in patients with laryngeal cancer. Controlled clinical studies]. Nowotwory, 1989, 39(2):111-5 [In Polish].

7. Shchepetkin IA. [Metronidazole effect on active oxygen production by human blood neutrophils]. Antibiotiki i khimioterapiia, 1997, 42(8):38-41 [In Russian].

8. Akamatsu $\mathrm{H}$, Horio $\mathrm{T}$. The possible role of reactive oxygen species generated by neutrophils in mediating acne inflammation. Dermatology, 1998, 196(1):82-5.

9. Brown JM. The hypoxic cell: a target for selective cancer therapy-eighteenth Bruce F. Cain Memorial Award lecture Cancer research, 1999, 59:5863-70.

10. Overgaard J. Clinical evaluation of nitroimidazoles as modifiers of hypoxia in solid tumors. Oncology research, 1994, 6:509-18. 
11. Rajendran JG et al. Hypoxia and glucose metabolism in malignant tumors: evaluation by [18F] fluoromisonidazole and [18F] fluorodeoxyglucose positron emission tomography imaging. Clinical cancer research, 2004, 10(7):2245-52.

12. Rogers MAJ, Powers EL, eds. Oxygen and oxyradicals in chemistry and biology. New York, Academic Press, 1981:34954.

13. Googman SI et al. Molecular cloning and expression of a cDNA encoding human electron transfer flavoprotein-ubiquinone oxidoreductase. European journal of biochemistry, 1994, 219:277-86.

14. Gordan JM, Walker CB. Current status systemic antibiotic usage in destruction of periodontal disease. Journal of periodontology, 1993, 64(Suppl. 1):760-71.

15. Eick $S$ et al. Clindamycin promotes phagocytosis and intracellular killing of periodontopathogenic bacteria by crevicular granulocytes: an in vitro study. Journal of antimicrobial chemotherapy, 2000, 46:583-8.

16. Van Vlem B et al. Immunomodulating effect of antibiotics: Literature review. Infection, 1996, 24:275-91.
17. Metcalf JA et al. Laboratory manual of neutrophil function. New York, Raven Press, 1986:100-5.

18. Al Hashimi AH, Al Krawi EA. A study of the redox and kinetic functional activity of respiratory bursts in normal granulocytes of human whole blood by means of lucigenin and luminal dependent CL. Basrah University Medical Journal, 2000, 18(2):22-5.

19. Shchepetkin IA, lur'ev SI. [Effect of metronidazole on luminol dependent chemiluminescence of neutrophils in whole blood of patients with chlamydial infection]. Antibiotiki i khimioterapiia, 1998, 43(3):31-6 [In Russian].

20. Davies NM, Jamali F. Pharmacological protection of NSAID-induced intestinal permeability in the rat: effect of tempo and metronidazole as potential free radical scavengers. Human \& experimental toxicology, 1997, 16:345-9.

21. Leite $A Z$ et al Protective effect of metronidazole on uncoupling mitochondrial oxidative phosphorylation induced by NSAID: a new mechanism. Gut, 2001, 48:163-7. 